\title{
A BIONIC EYE: PERFORMANCE OF THE ARGUS II RETINAL PROSTHESIS IN LOW-VISION AND SOCIAL REHABILITATION OF PATIENTS WITH END-STAGE RETINITIS PIGMENTOSA
}

Takhchidi KhP' ${ }^{1}$ Kachalina GF², Takhchidi NKh² , Manoyan RA², Gliznitsa PV1凶

Pirogov Russian National Medical Research University, Moscow, Russia

2 Scientific Clinical Center of Otorhinolaryngology, FMBA of Russia, Moscow, Russia

The death of outer retinal layers occurring in retinitis pigmentosa causes severe visual impairment and often leads to total blindness. Inner retinal layers are spared, though, which provides a possibility of inducing visual perception by direct electrical stimulation of intact retinal cells. This article presents clinical outcomes of two patients who were the first in Russia to have received the Argus II Retinal Prosthesis System. Both implantations were successful. No complications were reported throughout the entire follow-up period. Upon completing 3 rehabilitation sessions, the patients were able to navigate indoors and outdoors, locate small high-contrast objects, discern contours of large objects and people's silhouettes.

Keywords: bionic eye, artificial vision, retinal prosthesis, implant, Argus II, retinitis pigmentosa, retinal abiotrophy

Author contribution: Takhchidi KhP — study design, literature analysis, implantation surgery, data analysis and interpretation; Kachclina GF — study design, literature analysis, data analysis and interpretation; Takhchidi NKh — manuscript preparation, literature analysis; Manoyan RA — follow-up observation, rehabilitation sessions, data collection; Gliznitsa PV — follow-up observation, rehabilitation sessions, data collection, manuscript preparation.

Compliance with ethical standards: this clinical trial of the Argus II Retinal Prosthesis System was approved by the Ethics Committee of the National Research Clinical Center for Otorhinolaryngology (Protocol № 5/2017 dated June 14, 2017). The patients gave informed consent to participation in the trial and publication of their personal data.

Correspondence should be addressed: Pavel V. Gliznitsa Ostrovintyanova 1, Moscow, 117513; gliznitsap@icloud.com

Received: 04.06.2019 Accepted: 19.06.2019 Published online: 25.06.2019

DOI: 10.24075/brsmu.2019.042

\section{БИОНИЧЕСКИЙ ГЛАЗ: ВОЗМОЖНОСТИ ЭПИРЕТИНАЛЬНОЙ ПРОТЕЗНОЙ СИСТЕМЫ ARGUS II В ЗРИТЕЛЬНОЙ И СОЦИАЛЬНОЙ РЕАБИЛИТАЦИИ СЛЕПЫХ ПАЦИЕНТОВ С ТЕРМИНАЛЬНОЙ СТАДИЕЙ ПИГМЕНТНОГО РЕТИНИТА}

\author{
Х. П. Тахчидиㄹ, Г. Ф. Качалина ${ }^{2}$, Н. Х. Тахчиди², Р. А. Маноян², П. В. Глизница ${ }^{1 凶}$ \\ ${ }^{1}$ Российский национальный исследовательский медицинский университет имени Н. И. Пирогова, Москва, Россия \\ 2 Научно-клинический центр оториноларингологии ФМБА, Москва, Россия
}

При пигментном ретините происходит гибель наружных слоев сетчатки, сопровождающаяся значительными нарушениями зрительных функций вплоть до слепоты. Сохранность внутренних слоев сетчатки при данной патологии позволила разработать специальные устройства, использующие прямую электрическую стимуляцию для получения зрительного воспрития. В работе представлены результаты впервые проведенных в Российской Федерации двух операций по имплантации эпиретинальной протезной системы Argus II. Обе операции прошли успешно, осложнения отсутствовали на протяжении всего периода наблюдения. После прохождения трех курсов реабилитации пациенты приобрели навыки перемещения внутри помещения и на открытых пространствах, способны определять локализацию высококонтрастных мелких предметов, контуры больших предметов, силуэты людей. Ключевые слова: бионический глаз, искусственное зрение, эпиретинальный протез, имплантат, Argus II, пигментный ретинит, абиотрофия сетчатки

Информация о вкладе авторов: Х. П. Тахчиди - планирование исследования, анализ литературы, проведение хирургических операций, анализ и интерпретация данных; Г. Ф. Качалина — планирование исследования, анализ литературы, анализ и интерпретация данных; Н. Х. Тахчиди — подготовка рукописи, анализ литературы; Р. А. Маноян — курация, участие в реабилитации, сбор данных; П. В. Глизница — курация, участие в реабилитации, сбор данных, подготовка рукописи.

Соблюдение этических стандартов: клиническое исследование медицинского изделия «Система ретинальной имплантации Аrgus II с принадлежностями» одобрено этическим комитетом ФГБУ НКЦО ФМБА России (протокол № 5/2017 от 14 июня 2017 г.). Все пациенты подписали добровольное информированное согласие на участие в исследовании и публикацию результатов.

$\bigotimes$ Для корреспонденции: Павел Викторович Глизница

ул. Островитянова, д. 1, г. Москва, 117513; gliznitsap@icloud.com

Статья получена: 04.06.2019 Статья принята к печати: 19.06.2019 Опубликована онлайн: 25.06.2019

DOI: 10.24075/vrgmu.2019.042

Retinitis pigmentosa is a group of inherited disorders characterized by progressive degeneration of the retinal pigment epithelium and photoreceptors. Patients with retinitis pigmentosa gradually lose their side and night vision, suffer from decreased visual acuity and can eventually develop total blindness [1]. However, inner retinal layers (bipolar neurons, ganglion cells and the optic nerve layer) are not affected by the pathology [2, 3]. This provides a possibility of inducing visual perception in such patients by direct electrical stimulation of spared retinal cells using an implantable device $[4,5]$. To date, about 10 such projects have been launched worldwide.
The Argus II Retinal Prosthesis System is the most indemand retinal implant. So far, over 350 Argus devices have been implanted. Argus II has been approved for commercial use by the European Union. It has also received approval from the American Food and Drug Association (FDA) as a humanitarian use device [6, 7]. Argus II consists of externally worn equipment (a pair of glasses with an integrated video camera and a video processing unit) and an implantable unit (a scleral band, an electronics case, a receiving coil and an array of 60 electrodes, which is affixed to the retina). The video camera captures the scene; the obtained video signals are transformed 
by the processing unit and transmitted to the implant, which electrically stimulates intact retinal cells. The emitted pulses are perceived by the patient as patterns of light [8]. Ideally, one electrode will activate only its neighboring cells and induce visual perception in the form of circular spots of light, which is important for perceiving the shape of objects [9].

This study aimed to assess the use of the Argus II Retinal Prosthesis System in low-vision and social rehabilitation of blind patients with end-stage retinitis pigmentosa.

\section{METHODS}

The study was carried out at the facilities of the Scientific Research Center for Ophthalmology of Pirogov Russian National Medical Research University and the Scientific Clinical Center of Otorhinolaryngology. Two patients were selected from a list of 20 candidates with retinitis pigmentosa. Those 2 individuals were the first Russian patients to receive the Argus II Retinal Prosthesis System (Second Sight Inc.; USA). One patient underwent surgery on June 30, 2017; the other, on December 4, 2017.

The following implantation eligibility criteria were applied: end-stage retinitis pigmentosa; bare light perception; a previous history of useful form vision; age over 25 years. Contraindications for implantation included corneal opacity in the optical zone; optic nerve diseases; choroidal neovascularization; the axial eye length $<20.5 \mathrm{~mm}$ and $>26 \mathrm{~mm}$.

\section{Case 1}

Patient U., aged 58, was diagnosed with end-stage retinitis pigmentosa of both eyes and referred to our Clinical Research Center. His visual acuity was $(1 / \infty)$ pr. I. incertae for both eyes. Based on electroretinography findings, the right eye (OD) was selected as a better candidate for implantation.

Before surgery, visual acuity in OD was $(1 / \infty)$ pr. I. incertae and intraocular pressure was $16 \mathrm{mmHg}$. Biomicroscopy revealed no abnormalities in the anterior segment. Opacities were starting to form in the central zone of the lens. In the ocular fundus, the optic disc was pale, waxy, with sharp margins; blood vessels were attenuated. The anatomy of the macula was intact but a depigmented ring-shaped area was observed

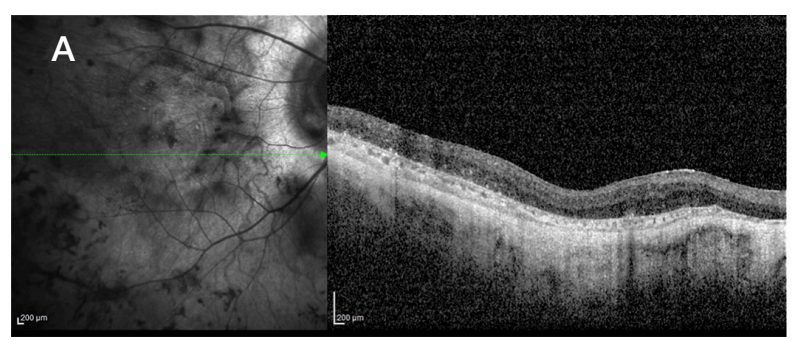

on the periphery. The macular reflex was absent. Perivascular bone spicule pigment deposits were noticed in the periphery; the retina was atrophied (Fig. 1A).

Retinal atrophy was confirmed by a crossline optical coherence tomography (OCT) scan performed with Spectralis OCT (Heidelberg Engineering, Inc.; Germany). The atrophy was the most pronounced in the outer layers. Measured by electroretinography, the perceptual threshold (PT) was $800 \mu \mathrm{A}$ and the flicker fusion rate was $60 \mathrm{~Hz}$.

Surgery was performed according to the protocol recommended by the manufacturer of the retinal prosthesis. It lasted 5 hours and consisted of the following stages: the natural lens was removed and an artificial intraocular lens was implanted; the scleral band with the electronics case was passed under the recti muscles, encircling the globe, and secured in place; subtotal vitrectomy was performed followed by the implantation of the intraocular segment of the prosthesis; the electrode array was secured to the retina in the macular zone with a retinal tack; the scleral wound and the conjunctiva were then closed.

\section{Case 2}

Female patient Z., aged 56, was diagnosed with end-stage retinitis pigmentosa of both eyes. Her visual acuity was $(1 / \infty)$ pr. I. incertae in both eyes. The OCT scan of the retina revealed that the patient was able to fix the gaze with her right eye. Therefore, the worse-seeing left eye was selected for surgery as recommended by the manufacturer of Argus II.

Before surgery, the patient's visual acuity was $(1 / \infty)$ pr. I. incertae in both eyes and intraocular pressure was $16 \mathrm{mmHg}$. Biomicroscopy revealed no abnormalities in the anterior segment. Opacities were starting to form in the central zone of the lens. In the ocular fundus, the optic disc was pale, waxy, with sharp margins; blood vessels were attenuated. The anatomy of the macula was intact; a depigmented ring-shaped area was observed on the periphery. The macular reflex was absent. Perivascular bone spicule pigment deposits were noticed in the periphery; the retina was atrophied (Fig. 2A). A crossline OCT scan revealed retinal atrophy that was very pronounced in outer retinal layers. Measured by electroretinography, the perceptual threshold (PT) was $500 \mu \mathrm{A}$ and the flicker fusion rate was $75 \mathrm{~Hz}$.

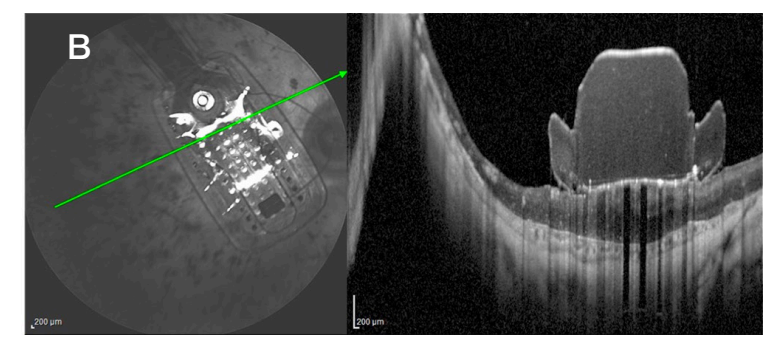

Fig. 1. OCT scans of patient U.'s right eye before (A) and after (B) implantation of Argus II show the correct position of the implant secured to the retina
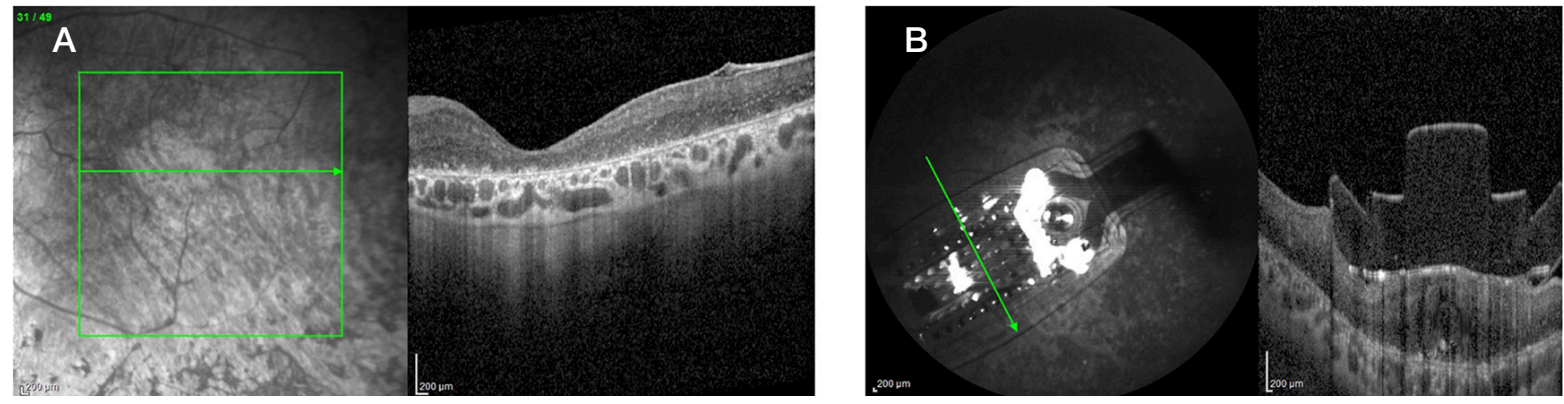

Fig. 2. OCT scans of patient Z.'s left eye before $(\mathbf{A})$ and after $(\mathbf{B})$ implantation of Argus II show the correct position of the implant secured to the retina 
Surgery, which lasted 4 hours, was performed according to the protocol described above.

\section{RESULTS}

The patients received 3 post-operative rehabilitation sessions each. During the sessions, they were trained to use the device both indoors and outdoors. Their visual function was assessed by 3 tests that were conducted in a darkened room using software and a touch screen monitor supplied by Second Sight (Fig. 3). In the Grating Visual Acuity test, black and white lines varying in width appeared on the screen. The lines were moving in different directions. The patient had to identify the direction of each line. In the Motion of Direction test, a white line was moving across the black screen in different directions. The task was to identify the direction of movement. In the third test called the Square Localization test differently sized white squares appeared in different parts of the black screen; the patient was asked to locate the square on the screen.

Patient 1 had no complications during or after implantation in the follow-up period. The medication therapy he received conformed to the guidelines provided by the implant's manufacturer. Two weeks after surgery, primary wound healing was observed; the wound showed no discharge or signs of inflammation. The scleral band and the electronics case were securely held in place. Ocular mobility was normal. The scleral and conjunctival wounds did not leak. Intraocular pressure measured by an Icare ${ }^{\circledast}$ PRO tonometer (iCare PRO; Finland) was 17-18 $\mathrm{mmHg}$. The cornea was transparent. The deep anterior chamber was filled with transparent fluid. The intraocular lens was well-centered. The electrode array was also held in place, fitting snugly against the retina (Fig. 1B).

The implant was activated 2 weeks after surgery as planned. Diagnostic testing revealed that all 60 electrodes conducted electric current. OCT showed that the array was fitted snugly against the retina. Impedance was measured for each electrode. Perceptual thresholds were determined from instrumentation readings and the patient's feedback. Because their values fell within the acceptable range, all 60 electrodes could be used to induce visual perception (Fig. 4A).

Once the implant was activated for custom fitting, the patient reported seeing flashes of light (phosphenes) of different shapes and shades. The first training session was conducted a month after surgery. During the session, the patient was taught basic skills needed to use the system. Two months after surgery, during the second session, the patient was trained to navigate indoors. He learnt to locate small high-contrast objects, identify contours of large objects, human silhouettes,

A

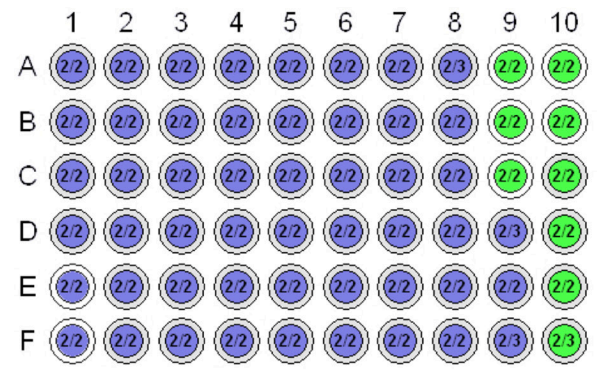

etc. (Fig. 5A). The third session was held in month 6 following the surgical procedure. The patient's visual function assessed by a number of tests continued to improve. Now he was able to navigate both indoors and outdoors. Tests showed that the patient performed better with the Argus 2 system on (Fig. 6).

Patient 2 also had no complications during or after implantation in the follow-up period. The medication therapy she received conformed to the guidelines provided by the implant's manufacturer. Two weeks after surgery, primary wound healing was observed; the wound showed no discharge or signs of inflammation. The scleral band and the electronics case were securely held in place. Ocular mobility was normal. The scleral and conjunctival wounds did not leak. Intraocular pressure measured by an Icare ${ }^{\circledR} \mathrm{PRO}$ tonometer (iCare PRO; Finland) was $16-17 \mathrm{mmHg}$. The cornea was transparent. The deep anterior chamber was filled with transparent fluid. The intraocular lens was well-centered. The electrode array was also held in place, fitting snugly against the retina (Fig. 2B).

The implant was activated 2 weeks after surgery as planned. Diagnostic testing revealed that all 60 electrodes conducted electric current. OCT showed that the array was fitted snugly against the retina. Impedance was measured for each electrode. Perceptual thresholds were determined from instrumentation readings and the patient's feedback. Three electrodes failed to induce visual perception at acceptable perceptual thresholds, so only the remaining 57 electrodes were used to stimulate spared retinal cells (Fig. 4B). Once the implant was activated, the patient reported seeing flashes of light of different shades and shapes. The patient was also immediately able to discern people's silhouettes (Fig. 5B).

In the first training session, the patient learnt basic skills needed to use the device. The second session took place in month 6 after surgery. The patient was taught to navigate indoors, locate small high-contrast objects, contours of large objects, people's silhouettes, etc. Tests showed that she performed better with the Argus 2 system on (Fig. 7).

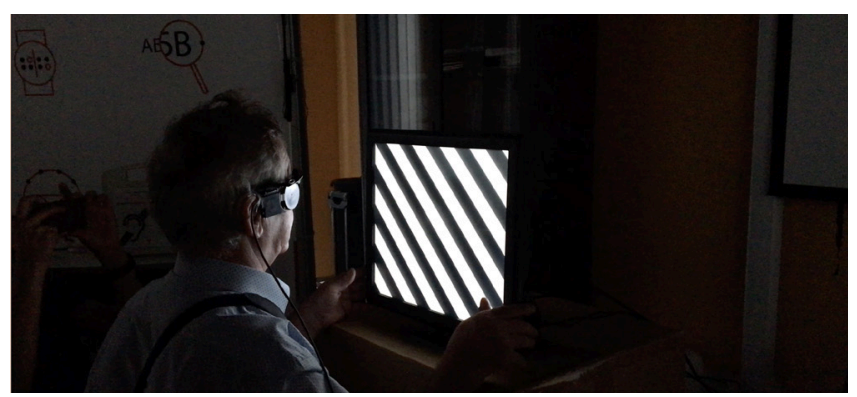

Fig. 3. Patient U. is taking a Grating Visual Acuity test

B

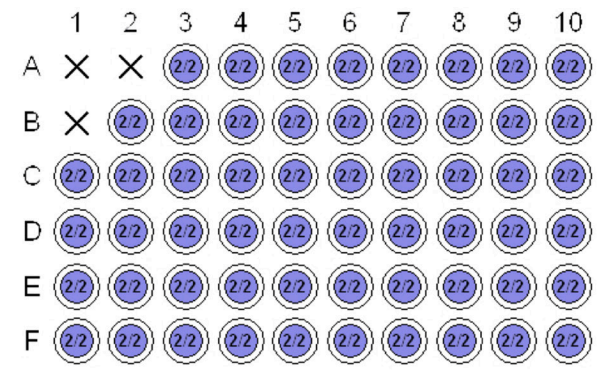

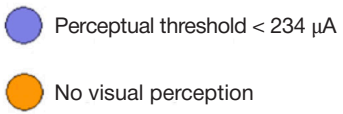

$\bigcirc$ Perceptual threshold $<677 \mu \mathrm{A}$

X Skipped

Fig. 4. Stimulation charts of the implants showing perceptual thresholds for each of 60 electrodes in patient U. (A) and patient Z. (B) 

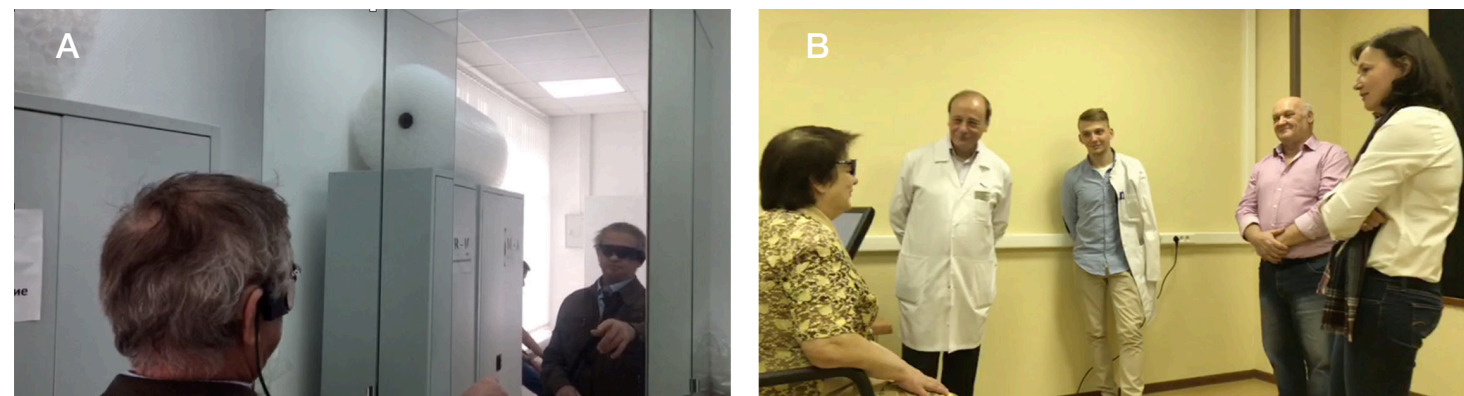

Fig. 5. Patient U. identifies a mirror before him and recognizes his own reflection (A). Patient Z. can correctly tell the number of people standing in front of her during the custom fitting session (B)

A
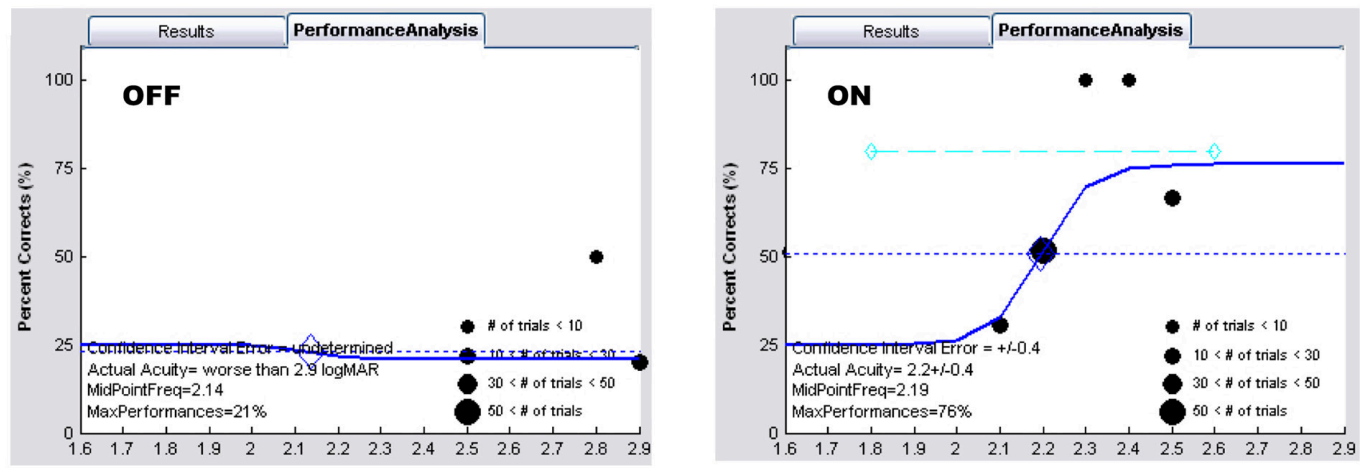

B

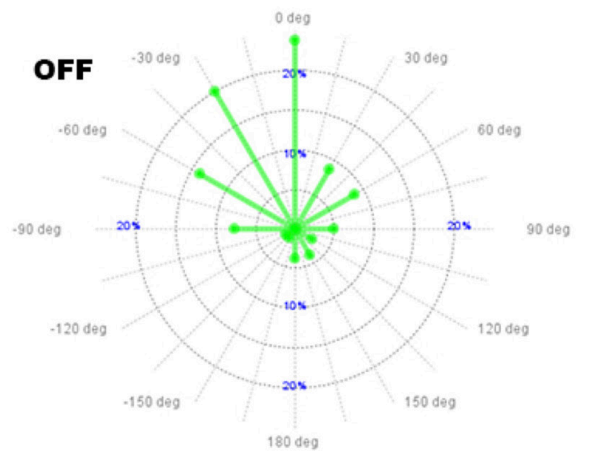

Number of correct answers: $19 / 80(23.75 \%)$

Standard error: $53.502^{\circ}$

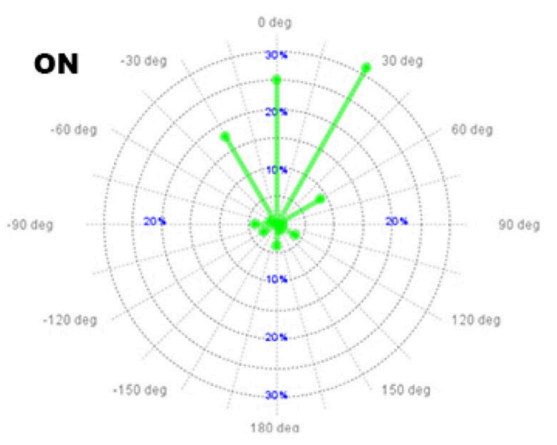

Number of correct answers: 20/80 (25.0\%)

Standard error: $43.29^{\circ}$

\section{C}
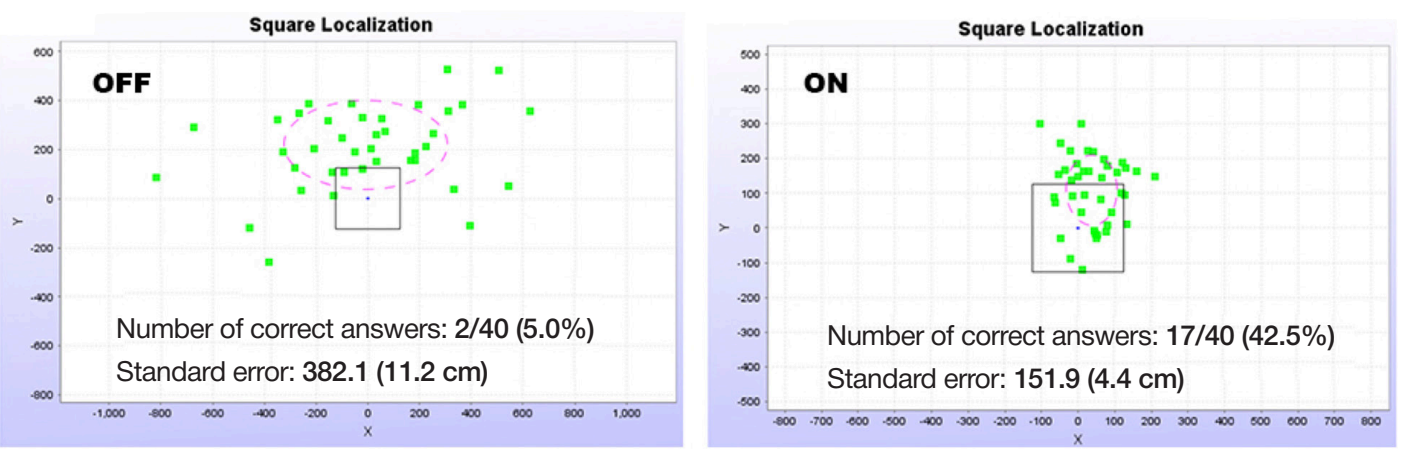

Fig. 6. Results of visual assessment computer tests done by patient U. with Argus II off and on: the Grating Visual Acuity Test (A); the Direction of Motion test (B); the Square Localization test (C)

After completing the basic rehabilitation course, both patients felt they did not require assistance at home: they were able to locate eating utensils and household appliances, could go from one room to another, etc. They could use public transport, take walks outdoors, go shopping, etc on their own. For safety reasons, the patients were accompanied by family or friends when taking new or long routes. At present, patient $U$. performs in his own magic show together with his dog all over Russia (Fig. 8A). Patient Z. has taken part in a Moscow fashion show (Fig. 8B). Both patients attend conferences on the problems of vision rehabilitation. 
A
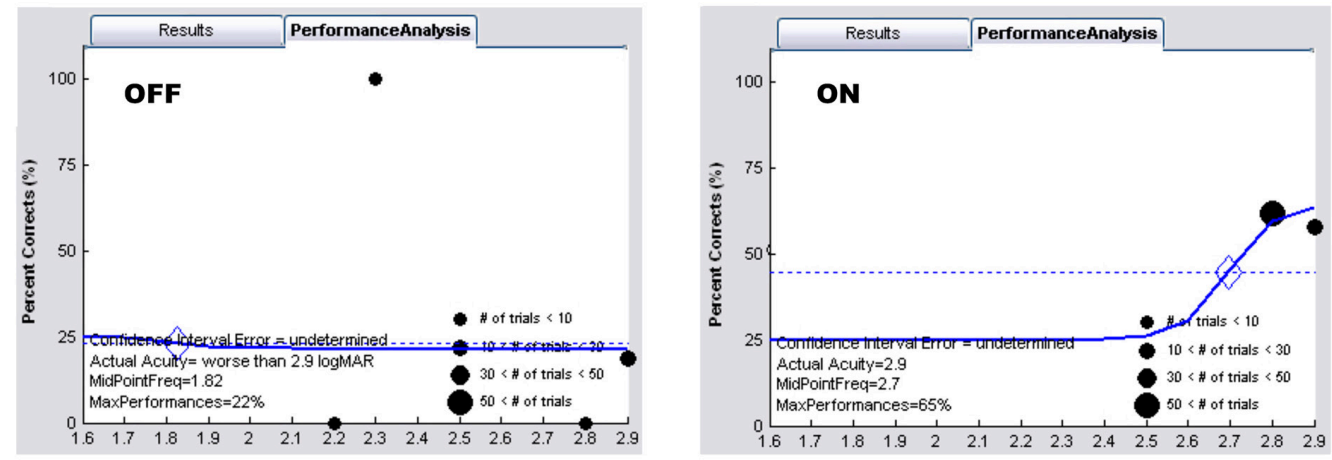

B

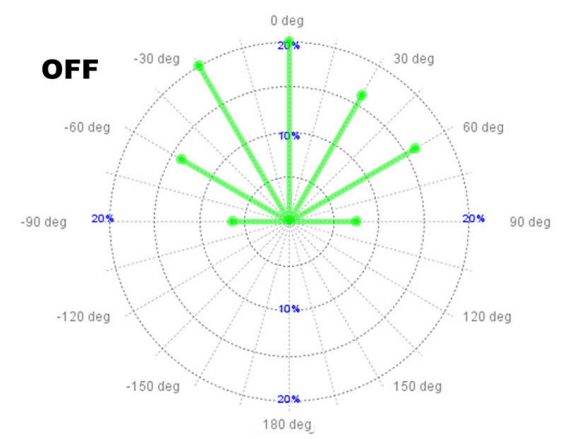

Number of correct answers: 16/80 (20.00\%)

Standard error: $42.31^{\circ}$

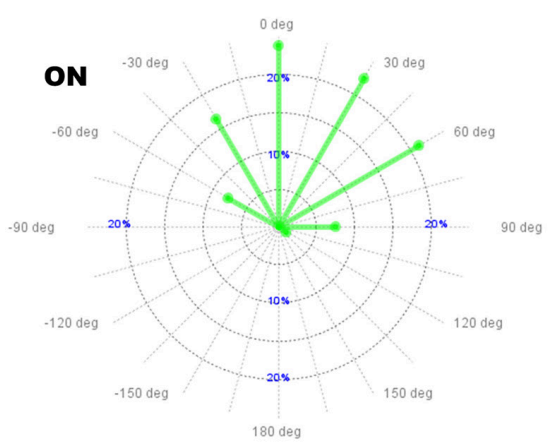

Number of correct answers: 19/80 (23.75\%)

Standard error: $37.04^{\circ}$

C
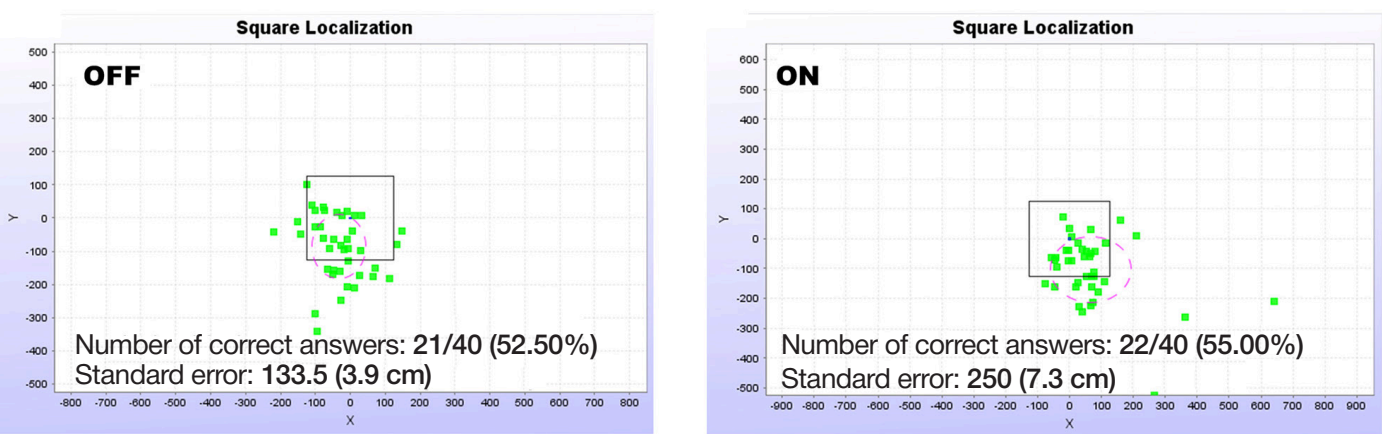

Fig. 7. Results of visual assessment computer tests done by patient Z. with Argus II off and on: the Grating Visual Acuity Test (A); the Direction of Motion test (B); the Square Localization test (C)
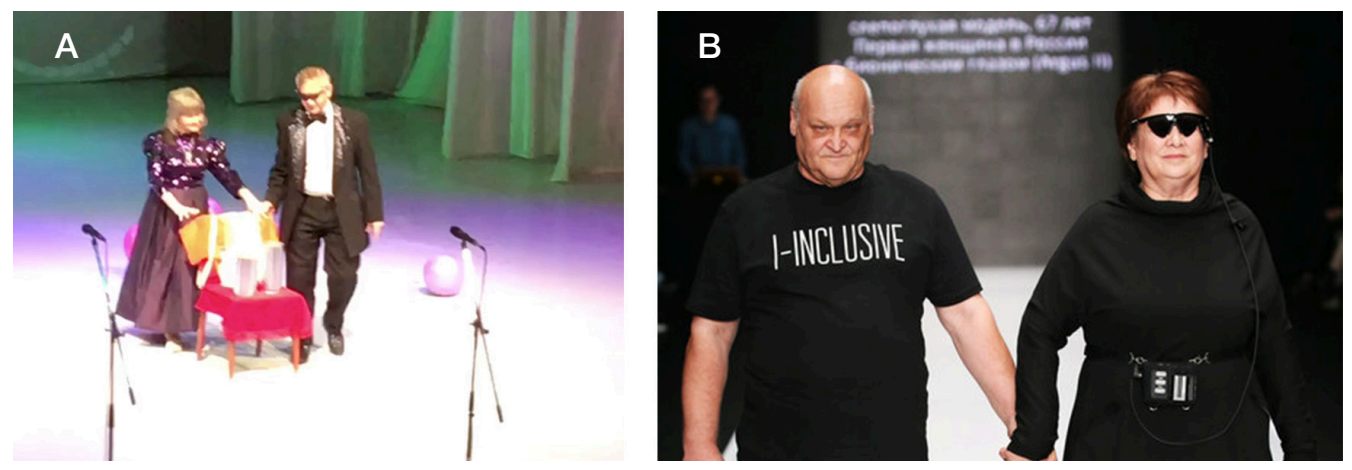

Fig. 8. Patient $U$. is giving a magic show in Chelyabinsk (A); patient Z. on a catwalk during a fashion show in Moscow (B)

\section{DISCUSSION}

A 5-year multicenter clinical efficacy and safety trial of Argus II in patients with retinitis pigmentosa has yielded the following results: visual perception was induced in 100\% of patient implanted with Argus II right upon activation of the implant; $96 \%$ of patients performed better in the Square Localization test with Argus II on; $57 \%$ of patients performed better in the Direction of Motion test with Argus II on; $23 \%$ of patients had measurable grating visual acuity with the implant on; post-operatively, the average number of functional electrodes in those patients was $43[10,11]$. Our 
patients performed better in each of the 3 tests with Argus II on, which places them in the group of individuals with the best clinical outcomes. No complications were observed in both patients during surgery and post operatively; all 60 electrodes were functional after implantation. Visual perception was successfully induced in both patients by activating 60 and 57 electrodes, respectively. In the second patient, 3 electrodes were turned off because they failed to induce visual perception at an acceptable perceptual threshold. Given that only $23 \%$ of all patients with an implanted Argus II prosthesis had measurable grating visual acuity over 2.9 LogMAR (Vis $=0.001)$ and that in patient $U$. grating visual acuity was 2.2 LogMAR (Vis $=0.006$ ) (Fig. 6A), we believe in the case of our patient, the clinical outcome was one of the best possible [8, 12].

Significant positive changes in the patients' social life were driven by their desire to see again, which encourage them to work hard on a daily basis to improve their Argus II skills. Socially, patients have benefited greatly from increasing attention to this unique technology that allows blind people to restore some vision.

\section{CONCLUSIONS}

The Argus II Retinal Prosthesis System is a robust tool that facilitates social and low-vision rehabilitation of blind patients with end-stage retinitis pigmentosa. Both patients are very satisfied with the results they have achieved. They are able to navigate indoors and outdoors without assistance and report that their quality of life has significantly improved. Success of Argus II demonstrates that 1) an interaction between a retinal implant and the natural retina can be effective in transmitting the collected video data into the visual cortex; 2) these data can be perceived by the cortex as visual in response to electrical stimulation of retinal neurons; 3) these visual data can be successfully used by patients with end-stage retinitis pigmentosa helping them to become less dependent on other people in their daily life, improve their social adaptation and ultimately enjoy a better quality of life.

\section{References}

1. Grüsser O-J, Hagner M. On the history of deformation phosphenes and the idea of internal light generated in the eye for the purpose of vision. History of Ophthalmology book series. ACOI. 1990; (3): 57-85.

2. Loewenstein JI, Montezuma SR, Rizzo JF. Outer retinal degeneration: an electronic retinal prosthesis as a treatment strategy. Arch Ophthalmol. 2004; 122 (4): 587-96.

3. Brelen ME, Duret F, Gerard B, Delbeke J, Veraart C. Creating a meaningful visual perception in blind volunteers by optic nerve stimulation. J Neural Eng. 2005; (2): 22-8.

4. Ghodasra DH, Chen A, Arevalo JF, et al. Worldwide Argus ॥ implantation: recommendations to optimize patient outcomes. BMC Ophthalmol. 2016; 16 (1): 52.

5. Humayun MS, de Juan E, Jr, Dagnelie G, Greenberg RJ, Propst RH, Phillips $\mathrm{DH}$. Visual perception elicited by electrical stimulation of retina in blind humans. Arch Ophthalmol. 1996; 114 (1): 40-6.

6. Mills JO, Jalil A, Stanga PE. Electronic retinal implants and artificial vision: journey and present. Eye (Lond). 2017 Oct; 31 (10): 1383-98.

7. Yue L, Weiland JD, Roska B, Humayun MS. Retinal stimulation

\section{Литература}

1. Grüsser O-J, Hagner M. On the history of deformation phosphenes and the idea of internal light generated in the eye for the purpose of vision. History of Ophthalmology book series. ACOI. 1990; (3): 57-85.

2. Loewenstein Jl, Montezuma SR, Rizzo JF. Outer retinal degeneration: an electronic retinal prosthesis as a treatment strategy. Arch Ophthalmol. 2004; 122 (4): 587-96.

3. Brelen ME, Duret F, Gerard B, Delbeke J, Veraart C. Creating a meaningful visual perception in blind volunteers by optic nerve stimulation. J Neural Eng. 2005; (2): 22-8.

4. Ghodasra DH, Chen A, Arevalo JF, et al. Worldwide Argus II implantation: recommendations to optimize patient outcomes. BMC Ophthalmol. 2016; 16 (1): 52.

5. Humayun MS, de Juan E, Jr, Dagnelie G, Greenberg RJ, Propst RH, Phillips DH. Visual perception elicited by electrical stimulation of retina in blind humans. Arch Ophthalmol. 1996; 114 (1): 40-6.

6. Mills JO, Jalil A, Stanga PE. Electronic retinal implants and artificial vision: journey and present. Eye (Lond). 2017 Oct; 31 (10): 1383-98.

7. Yue L, Weiland JD, Roska B, Humayun MS. Retinal stimulation

strategies to restore vision: Fundamentals and systems. Prog Retin Eye Res. 2016 Jul; 53: 21-47.

8. da Cruz L, Dorn JD, Humayun MS, Dagnelie G, Handa J, Barale P-O, et al. Five-Year Safety and Performance Results from the Argus II Retinal Prosthesis System Clinical Trial. Ophthalmology. 2016 Oct; 123 (10): 2248-54.

9. Chader GJ, Weiland J, Humayun MS. Artificial vision: needs, functioning, and testing of a retinal electronic prosthesis. Prog Brain Res. 2009; (175): 317-32.

10. Tran BK, Wolfensberger TJ. Retina-Implant Interaction after 16 Months Follow-up in a Patient with an Argus II Prosthesis. Klin Monbl Augenheilkd. 2017 Apr; 234 (4): 538-40.

11. de Balthasar C, Patel S, Roy A, et al. Factors a ec ng perceptual thresholds in epirenal prostheses. Invest Ophthalmol Vis Sci. 2008; 49 (6): 2303-14

12. Besch D, Sachs H, Szurman P, et al. Extraocular surgery for implantation of an active subretinal visual prosthesis with external connections: feasibility and outcome in seven patients. $\mathrm{Br} J$ Ophthalmol. 2008; (92): 1361-8. 